\title{
State and structure of urban forests in Kharkiv region
}

\author{
Sergiy Musienko ${ }^{1}$, Oleksandr Lyalin ${ }^{1}$, Ludmila Tkach $^{1}$, Vira Bondarenko ${ }^{1}$, \\ Marina Kolenkina ${ }^{1}$, Olena Kolchanova ${ }^{2} \bowtie$ \\ ${ }^{1}$ O.M. Beketov National University of Urban Economy in Kharkiv, Marshal Bazhanov 17, Kharkiv, 61002, Ukraine \\ ${ }^{2}$ State Enterprise Vinnytsia Forest Research Station, Maksymovycha 39, Vinnytsia, 21036, Ukraine, \\ e-mail: olena.kolchanova@gmail.com
}

\begin{abstract}
Deterioration of water conservation, water protection, water-regulating, soil-protective, health and recreational properties of urban forests is an urgent problem in urban areas. Researching the state and growth characteristics of urban forests will help in developing the best forestry management activities of care. The objects of study were the urban forests of Kharkiv region. During the study, methods commonly used in forestry, forest inventory and biometrics were applied. The investigation determined a species range of urban forests and prevailing species in terms of users. The stands' distribution by species composition, age groups, their average age, site class, stand density and timber volume was determined. The practicability of further research of these objects was proved.
\end{abstract}

\section{KeY WORDS}

urban forest structure, urban areas, state enterprises, environmental condition

\section{INTRODUCTION}

The city is sometimes called a giant ecosystem, but it is hard to agree with such definition. In ecosystems of urban areas, there is usually no state of dynamic equilibrium. In cities, construction works are constantly in progression that changes not only relief but also conditions of an underground environment: there are local soil subsidence, karst cavities, underflooding and others. The soil loses its natural qualities. Polluting emissions into the air from transport and industrial enterprises induce growing air and soil pollution, which in turn adversely affects the flora and fauna. An additional factor that is essential is a recreational activity. These circumstances have prompted researchers to formulate the concept of 'urboecosystem', natural and urban systems consisting of fragments of natural ecosystems, surrounded by houses, industrial zones, highways and so on (Tokareva 2004; Stolberg 2000).

Forests of urban areas serve to protect the air of cities and industrial centres from the harmful effects of dust, carbonic acid and toxic gas (hydrogen sulphide, hydrogen fluoride, carbon dioxide, sulfur and nitrogen oxides, hydrochloric acid vapor and so on).

A hectare of forest plantations is capable of annually filtering and precipitating up to 50-70 tons of dust, thus healing the environment (Sviridenko 1989). Deciduous forests have a high gas-absorbing ability.

Urban forests are used by citizens as a place of recreation. Clean air, a beauty of forest nature, peace and 
quietness provide relaxation, rapid readaptation to work and human health. At the same time, human impact on planting often causes extremely undesirable effects: reducing the protective functions of forests and their aesthetic value and inducing gradual degradation (Alvey 2006; Miller et al. 2015; Basos 2008).

Research on the structure and characteristics of urban forest growth will allow creating optimal plantations for urban areas that will strengthen their water conservation, water protection, water regulating, soilprotective, health and recreational properties.

\section{Material AND Methods}

The current state of urban forests was analysed and studied following the data of the last basic forest survey and the content of 'Forests of Ukraine 2010' subcompartment database. Calculations were performed using modern information technologies and computer engineering. The forest stand areas were distributed by species, land use categories, diameter, height, density, forest site capacity, age classes and other mensuration indicators in the context of users. The study was conducted using standard methods of forestry, forest science and forest mensuration (Vorobyov 1967; Anuchin 1982).

The analysis of urban forests was carried out based on the electronic database of the 'Ukrderzhlisproekt' Production Association. The forest surveying database was converted from .vff to .mdb format for MS Access software using the program developed in the Laboratory of New Information Technologies of Ukrainian Research Institute of Forestry and Forest Melioration.

The query was generated in the database designed in the ACCESS format using four layouts: forest growth conditions (GROWCOND), subcompartment (PLOT), layer (LAYER) and tree stand (STAND).

Region (REGN), forest economy (FADM), forestry (FORY), compartment (KVRT), protection category (PROT), subcompartment (PLOT) and subplot (SPLT) fields were common for the layouts.

In addition, the query included predominant species (KAPL), site class (KAB), forest type (KATL), forest site type (KATU), age group (KAGV) and origin (KAPH1) fields from the forest growth conditions (GROWCOND) layout.
From the subcompartment (PLOT) layout, the land category (KAKZ), year of the last inventory (KAVQ) and area (SQUARE) fields were included in the query.

From the layer (LAYER) layout, the layer (LAYR), stand density (KAP_), stock per hectare (KAMG) and layer stock (KAMJ) fields were included in the query.

The following fields were added to the query from the stand (STAND) layout: the species number in a subcompartment (nPage), species (KASP), origin (KAPH2), age (KAA_), diameter (KAD_), composition (KASS), height (KAH_), the percentage of merchantable wood (KAND), total cross-sectional area (KAGS) and subcompartment stock (KAMQ).

Taking into account the fact that the urban forests were investigated, the query was narrowed to the corresponding protection categories. The generated query was exported to MS EXCEL for further analysis (Vedmid et al. 2006; Musienko et al. 2018).

\section{Results}

The total forest area of Ukraine is 10.4 million ha, 9.6 million ha of which are covered with forest vegetation. Forest coverage of the country is $15.9 \%$. In a 50 year period, the forest area has increased by $21 \%$ and the timber volume has grown almost three times. Timber volume in forests is estimated to be within 2.1 billion $\mathrm{m}^{3}$. The total area of urban forests in Ukraine is about 51,000 ha (Tkach 2012). The largest share of the area is accounted for by the middle-aged stands (45\%). The area of mature and overmature forests is almost $17 \%$. The average age of the stands is about 60 years. There is a gradual ageing of forests that negatively affects their health condition.

Forests of Ukraine are formed by more than 30 tree species, among which Scots pine (Pinus sylvestris L.), English oak (Quercus robur L.), European beech ( $\mathrm{Fa}$ gus sylvatica L.), silver birch (Betula pendula Roth.), common alder (Alnus glutinosa (L.) Gaertn.), common ash (Fraxinus excelsior L.), European hornbeam (Carpinus betulus L.) and silver fir (Abies alba Mill.) are dominant. Coniferous plantations occupy $43 \%$ of the total area, including $35 \%$ of pine. Hardwood stands (oak, beech) account for $37 \%$ of the total area.

The majority of forests are state-owned. About 1.3 million ha (13\%) of forestry-designated land being 
in sustained use of municipal enterprises subordinated to local government authorities can be attributed to municipal ownership during the division of land. The proportion of forests under private ownership is less than $0.1 \%$ of the total area of forest land. About 0.8 million ha of forest lands under the state ownership are not provided for use and have been assigned to reserve lands.

Assignment of state forests by numerous permanent forest users has developed in Ukraine historically. For forest management, forests are assigned to use in perpetuity to enterprises, institutions and organisations of several tens of ministries and agencies. According to subordination, the largest area of forest land (about $73 \%$ ) is in use of forestry enterprises of the State Forest Resources Agency of Ukraine (Forest Code of Ukraine 1994).

The total area of forest fund of the Kharkiv region is 415.5 thousand ha, including 378.3 thousand ha covered with forest vegetation (Fig. 1). The total area of urban forests of this region is about 3,000 ha. Their timber volume is about 69 million $\mathrm{m}^{3}$. The largest area is occupied by middle-aged stands $(64 \%)$. The young

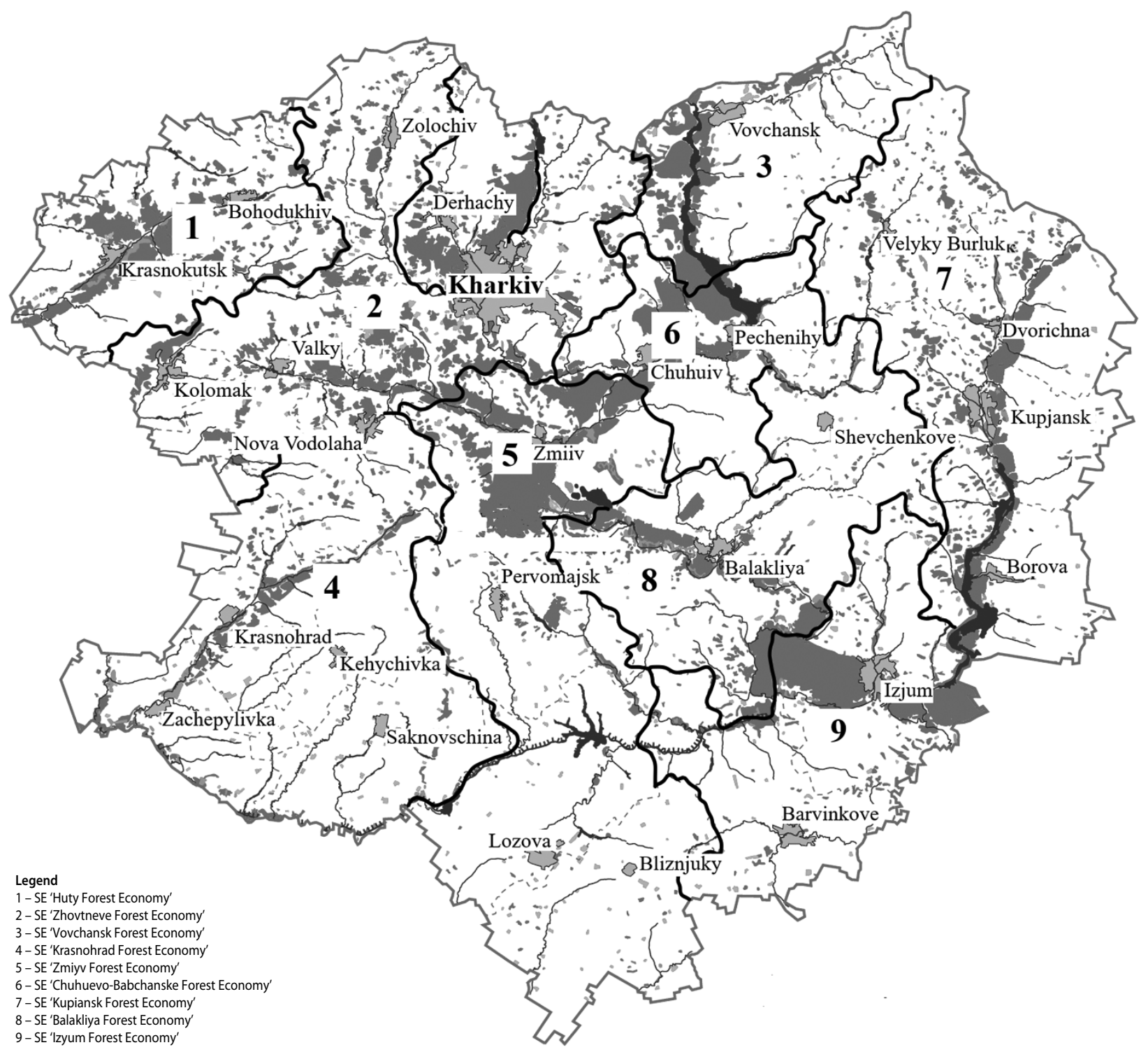

Figure 1. The schematic map forests of Kharkiv region 
Table 1. Distribution of stands by the predominant species in terms of enterprises

\begin{tabular}{|c|c|c|c|c|c|c|c|c|c|c|}
\hline \multirow[b]{2}{*}{ Predominant species } & \multicolumn{9}{|c|}{ User, ha/\% $\%$} & \multirow[b]{2}{*}{ Total, ha } \\
\hline & 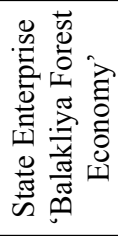 & 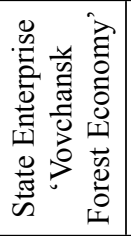 & 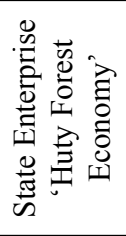 & 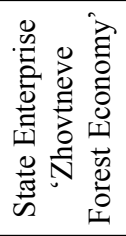 & 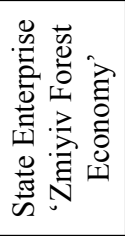 & 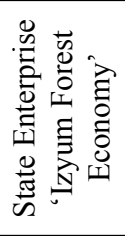 & 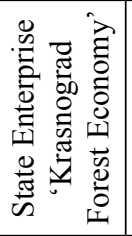 & 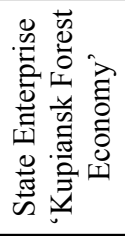 & 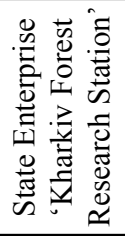 & \\
\hline $\begin{array}{l}\text { Siberian apricot } \\
\text { (Prunus armeniaca L.) }\end{array}$ & - & $\begin{array}{l}0.4 / \\
0.1\end{array}$ & - & - & - & - & - & - & - & 0.4 \\
\hline $\begin{array}{l}\text { Black locust (Robinia } \\
\text { pseudoacacia L.) }\end{array}$ & - & - & $\begin{array}{l}35.8 / \\
13.1\end{array}$ & - & - & $\begin{array}{l}8.2 / \\
4.3\end{array}$ & - & - & $\begin{array}{l}6.4 / \\
0.6\end{array}$ & 50.4 \\
\hline $\begin{array}{l}\text { Silver birch (Betula } \\
\text { pendula } \text { Roth.) }\end{array}$ & - & $\begin{array}{l}3.0 / \\
1.0\end{array}$ & $\begin{array}{l}2.7 / \\
1.0\end{array}$ & $\begin{array}{c}22.9 / \\
4.5\end{array}$ & - & - & - & - & $\begin{array}{c}24.2 / \\
2.1\end{array}$ & 52.8 \\
\hline $\begin{array}{l}\text { Field elm (Ulmus } \\
\text { minor Mill.) }\end{array}$ & - & - & - & - & - & - & - & - & $\begin{array}{l}3.6 / \\
0.3\end{array}$ & 3.6 \\
\hline $\begin{array}{l}\text { White willow (Salix } \\
\text { alba L.) }\end{array}$ & - & - & - & - & - & $\begin{array}{c}18.9 / \\
9.9\end{array}$ & - & - & - & 18.9 \\
\hline $\begin{array}{l}\text { Common alder (Alnus } \\
\text { glutinosa (L.) Gaertn.) }\end{array}$ & - & $\begin{array}{l}1.4 / \\
0.5\end{array}$ & - & $\begin{array}{l}6.7 / \\
1.3\end{array}$ & - & $\begin{array}{l}0.3 / \\
0.2\end{array}$ & - & - & $\begin{array}{l}5.8 / \\
0.5\end{array}$ & 14.2 \\
\hline $\begin{array}{l}\text { European pear (Pyrus } \\
\text { communis L.) }\end{array}$ & - & - & - & - & $\begin{array}{l}0.5 / \\
0.4\end{array}$ & - & - & - & - & 0.5 \\
\hline $\begin{array}{l}\text { English oak (Quercus } \\
\text { robur L.) }\end{array}$ & $\begin{array}{c}3.7 / \\
100.0\end{array}$ & - & $\begin{array}{c}24.2 / \\
8.9\end{array}$ & - & $\begin{array}{l}82.4 / \\
71.0\end{array}$ & $\begin{array}{l}27.7 / \\
14.5\end{array}$ & - & $\begin{array}{l}7.8 / \\
75.0\end{array}$ & $\begin{array}{c}1,027.6 / \\
88.4\end{array}$ & $1,173.4$ \\
\hline $\begin{array}{l}\text { Red oak (Quercus } \\
\text { rubra L.) }\end{array}$ & - & - & - & $\begin{array}{l}1.1 / \\
0.2\end{array}$ & - & - & - & - & $\begin{array}{l}2.1 / \\
0.2 \\
\end{array}$ & 3.2 \\
\hline $\begin{array}{l}\text { Norway maple (Acer } \\
\text { platanoides L.) }\end{array}$ & - & - & $\begin{array}{l}6.7 / \\
2.5\end{array}$ & - & $\begin{array}{l}6.5 / \\
5.6\end{array}$ & - & - & - & $\begin{array}{c}13.7 / \\
1.2\end{array}$ & 26.9 \\
\hline $\begin{array}{l}\text { Ash-leafed maple } \\
\text { (Acer negundo L.) }\end{array}$ & - & $\begin{array}{l}0.3 / \\
0.1 \\
\end{array}$ & - & - & - & $\begin{array}{c}15.2 / \\
7.9 \\
\end{array}$ & - & - & - & 15.5 \\
\hline $\begin{array}{l}\text { Small-leafed lime } \\
\text { (Tilia cordata Mill.) }\end{array}$ & - & - & - & - & - & - & - & - & $\begin{array}{l}2.3 / \\
0.2 \\
\end{array}$ & 2.3 \\
\hline $\begin{array}{l}\text { Common aspen } \\
\text { (Populus tremula L.) }\end{array}$ & - & $\begin{array}{l}5.4 / \\
1.8 \\
\end{array}$ & $\begin{array}{l}0.8 / \\
0.3 \\
\end{array}$ & - & - & $\begin{array}{l}1.1 / \\
0.6\end{array}$ & - & - & - & 7.3 \\
\hline $\begin{array}{l}\text { Scots pine (Pinus } \\
\text { sylvestris } \mathrm{L} .)\end{array}$ & - & $\begin{array}{c}279.0 / \\
95.1\end{array}$ & $\begin{array}{c}195.8 / \\
71.6\end{array}$ & $\begin{array}{c}475.1 / \\
93.9\end{array}$ & - & $\begin{array}{l}28.2 / \\
14.7\end{array}$ & - & - & $\begin{array}{c}64.0 / \\
5.5\end{array}$ & $1,042.1$ \\
\hline $\begin{array}{l}\text { White poplar (Populus } \\
\text { alba L.) }\end{array}$ & - & - & $\begin{array}{l}1.3 / \\
0.5 \\
\end{array}$ & $\begin{array}{l}0.7 / \\
0.1 \\
\end{array}$ & $\begin{array}{l}1.1 / \\
0.9 \\
\end{array}$ & $\begin{array}{l}65.6 / \\
34.1 \\
\end{array}$ & - & - & $\begin{array}{l}2.4 / \\
0.2 \\
\end{array}$ & 71.1 \\
\hline $\begin{array}{l}\text { Bolle's poplar } \\
\text { (Populus alba } \mathrm{L} . \text { var. } \\
\text { pyramidalis Bge.) }\end{array}$ & - & - & - & - & $\begin{array}{c}0.2 / \\
0.2\end{array}$ & - & - & - & - & 0.2 \\
\hline $\begin{array}{l}\text { Canadian poplar } \\
\text { (Populus deltoides } \\
\text { Marsch.) }\end{array}$ & - & $\begin{array}{c}4.1 / \\
1.4\end{array}$ & $\begin{array}{c}0.3 / \\
0.1\end{array}$ & - & - & - & $\begin{array}{c}0.4 / \\
100.0\end{array}$ & - & - & 4.8 \\
\hline $\begin{array}{l}\text { Black poplar (Populus } \\
\text { nigra L.) }\end{array}$ & - & - & $\begin{array}{l}2.4 / \\
0.9 \\
\end{array}$ & - & - & $\begin{array}{l}25.4 / \\
13.3 \\
\end{array}$ & - & - & $\begin{array}{l}4.8 / \\
0.4 \\
\end{array}$ & 32.6 \\
\hline $\begin{array}{l}\text { Common ash } \\
\text { (Fraxinus excelsior L.) }\end{array}$ & - & - & $\begin{array}{l}3.0 / \\
1.1\end{array}$ & - & $\begin{array}{l}25.5 / \\
21.9\end{array}$ & - & - & $\begin{array}{l}2.6 / \\
25.0\end{array}$ & $\begin{array}{l}4.9 / \\
0.4\end{array}$ & 36.0 \\
\hline $\begin{array}{l}\text { Green ash Fraxinus } \\
\text { lanceolata } \text { Borkh. }\end{array}$ & - & - & - & - & - & $\begin{array}{l}0.9 / \\
0.5\end{array}$ & - & - & - & 0.9 \\
\hline Total, ha & 3.7 & 293.6 & 273.0 & 506.5 & 116.2 & 191.5 & 0.4 & 10.4 & $1,161.8$ & $2,557.1$ \\
\hline
\end{tabular}


stand area is $10 \%$, the stands of approaching maturity constitute $13 \%$, and mature and overmature stands occupy $13 \%$. The average age of the stands is 70 years.

The most widespread species are silver birch (B. pendula), black locust (Robinia pseudoacacia L.), common alder (A. glutinosa), English oak (Q. robur), Norway maple (Acer platanoides L.), field maple (Acer campestre L.), small-leafed lime (Tilia cordata Mill.), common aspen (Populus tremula L.), Scots pine (P. sylvestris), white poplar ( $P$. alba L.) and common ash (Fraxinus excelsior). Among them, English oak and Scots pine are the predominant species, which occupy $54 \%$ and $32 \%$ of the area covered with forest vegetation, respectively (Kurakin 2006).

Forests in the region are used by different users. The main forest area (319.5 thousand ha, or $76.1 \%$ ) is within the jurisdiction of the State Forest Resources Agency of Ukraine. According to the Forest Code of Ukraine, the State Forest Resources Agency of Ukraine controls the general forest management and forest law compliance. The authorised body for the above issues in the region is Kharkiv Regional Department of Forestry and Hunting and the state forest economies located in the region, namely the State Enterprise 'Balakliya Forest Economy', the State Enterprise 'Vovchansk Forest Economy', State Enterprise 'Huty Forest Economy', State Enterprise 'Zhovtneve Forest Economy', State Enterprise 'Zmiyiv Forest Economy', State Enterprise 'Izyum Forest Economy', State Enterprise 'Krasnograd
Forest Economy', State Enterprise 'Kupiansk Forest Economy', State Enterprise 'Kharkiv Forest Research Station', State Enterprise 'Chuhuivo-Babchanske Forest Economy' and National Natural Park 'Homilshanski Lisy'.

Since urban state-owned forests in Kharkiv region occupy the largest area, they became the subject of our research.

In these forests, the area covered with forest vegetation is 2,557.1 ha, including 1,496.6 ha of forest plantations. The timber volume is about 64 million $\mathrm{m}^{3}$. Area distribution of the stands presented in Table 1 shows that the predominant species in urban state-owned forests are oak and pine ( $45.9 \%$ and $40.7 \%$, respectively). A small share (13.4\%) is accounted for by other species.

The stand structure based on age is an important indicator in assessing forest resources. Age of stands is one of the principal forest mensuration indicators for planning most forest management activities and estimating forest productivity. It is, therefore, advisable to analyse the distribution of urban forest area by age groups depending on the user (Tab. 2). These stands are distinguished not only by species composition, but also by age, as evidenced by the data in Table 2 .

The average forest mensuration indicators were obtained in the research, which characterise urban forests depending on the user (Tab. 3). The stands are also characterised by different productivity, as we can see in Table 3.

Table 2. Stands distribution by age groups in terms of enterprises

\begin{tabular}{|c|c|c|c|c|c|c|c|c|c|c|}
\hline \multirow[b]{2}{*}{ Age group } & \multicolumn{9}{|c|}{ User, ha/\% } & \multirow[b]{2}{*}{ Total, ha } \\
\hline & 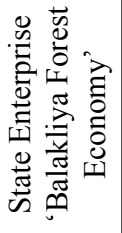 & 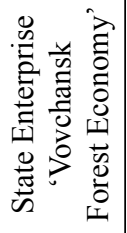 & 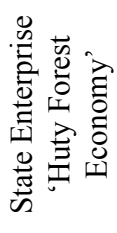 & 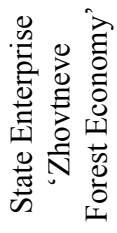 & 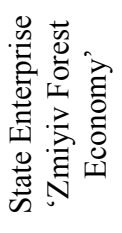 & 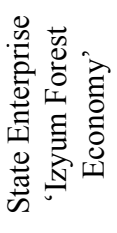 & 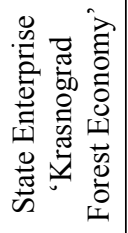 & 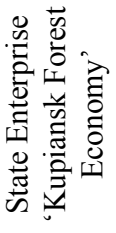 & 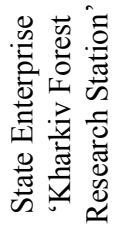 & \\
\hline Young stands & - & $\begin{array}{l}67.8 / \\
23.1\end{array}$ & $\begin{array}{l}58.2 / \\
21.3\end{array}$ & $\begin{array}{c}26.9 / \\
5.3\end{array}$ & $\begin{array}{l}0.6 / \\
0.5\end{array}$ & $\begin{array}{c}14.6 / \\
7.6\end{array}$ & - & - & $\begin{array}{l}7.3 / \\
0.6\end{array}$ & 175.4 \\
\hline Middle-aged stands & $\begin{array}{c}3.7 / \\
100.0\end{array}$ & $\begin{array}{c}221.0 / \\
75.3\end{array}$ & $\begin{array}{c}174.9 / \\
64.1\end{array}$ & $\begin{array}{c}471.3 / \\
93.1\end{array}$ & $\begin{array}{l}88.3 / \\
76.0\end{array}$ & $\begin{array}{l}59.3 / \\
31.0\end{array}$ & - & - & $\begin{array}{c}1,012.8 / \\
87.2\end{array}$ & $2,031.3$ \\
\hline $\begin{array}{l}\text { Stands of approaching } \\
\text { maturity }\end{array}$ & - & $\begin{array}{l}0.7 / \\
0.2\end{array}$ & $\begin{array}{l}1.9 / \\
0.7\end{array}$ & $\begin{array}{l}7.6 / \\
1.5\end{array}$ & $\begin{array}{l}26.0 / \\
22.4\end{array}$ & $\begin{array}{c}12.8 / \\
6.7\end{array}$ & - & $\begin{array}{l}6.9 / \\
66.3\end{array}$ & $\begin{array}{c}119.9 / \\
10.3\end{array}$ & 175.8 \\
\hline $\begin{array}{l}\text { Mature and overmature } \\
\text { stands }\end{array}$ & - & $\begin{array}{l}4.1 / \\
1.4\end{array}$ & $\begin{array}{c}38.0 / \\
13.9\end{array}$ & $\begin{array}{c}0.7 / \\
0.1\end{array}$ & $\begin{array}{l}1.3 / \\
1.1\end{array}$ & $\begin{array}{c}104.8 / \\
54.7\end{array}$ & $\begin{array}{c}0.4 / \\
100.0\end{array}$ & $\begin{array}{l}3.5 / \\
33.7\end{array}$ & $\begin{array}{c}21.8 / \\
1.9\end{array}$ & 174.6 \\
\hline Total, ha & 3.7 & 293.6 & 273.0 & 506.5 & 116.2 & 191.5 & 0.4 & 10.4 & $1,161.8$ & $2,557.1$ \\
\hline
\end{tabular}


Table 3. Dynamics of average forest mensuration indicators by users

\begin{tabular}{|c|c|c|c|c|c|}
\hline \multirow{3}{*}{ User } & \multicolumn{5}{|c|}{ Average forest mensuration indicator } \\
\hline & \multirow{2}{*}{$\begin{array}{l}\text { age, } \\
\text { years }\end{array}$} & \multirow{2}{*}{$\begin{array}{l}\text { site } \\
\text { class }\end{array}$} & \multirow{2}{*}{$\begin{array}{c}\text { stand } \\
\text { density }\end{array}$} & \multicolumn{2}{|c|}{$\begin{array}{l}\text { growing stock volume } \\
\text { per hectare, } \mathrm{m}^{3}\end{array}$} \\
\hline & & & & $\begin{array}{l}\text { lands covered with } \\
\text { forest vegetation }\end{array}$ & $\begin{array}{c}\text { mature and } \\
\text { overmature stands }\end{array}$ \\
\hline State Enterprise 'Balakliya Forest Economy' & 59 & $\mathrm{I}, 3$ & 0.66 & 208 & - \\
\hline State Enterprise 'Vovchansk Forest Economy' & 54 & I & 0.71 & 321 & 172 \\
\hline State Enterprise 'Huty Forest Economy' & 55 & $\mathrm{I}, 6$ & 0.72 & 224 & 149 \\
\hline State Enterprise 'Zhovtneve Forest Economy' & 64 & $\mathrm{I}, 9$ & 0.74 & 265 & 202 \\
\hline State Enterprise 'Zmiyiv Forest Economy’ & 65 & II,6 & 0.71 & 192 & 426 \\
\hline State Enterprise 'Izyum Forest Economy' & 46 & $\mathrm{II}, 8$ & 0.56 & 196 & 221 \\
\hline State Enterprise 'Krasnograd Forest Economy’ & 34 & IV & 0.62 & 151 & 151 \\
\hline State Enterprise 'Kupiansk Forest Economy’ & 75 & II,, 8 & 0.71 & 214 & 241 \\
\hline State Enterprise 'Kharkiv Forest Research Station' & 75 & II, 1 & 0.73 & 246 & 225 \\
\hline Total for all users & 66 & $\mathrm{I}, 9$ & 0.71 & 250 & 206 \\
\hline
\end{tabular}

\section{Discussion}

Kharkiv urban forests occupy a small area (about 1\%) as compared to the forest area of the Kharkiv region. Forest cover of Kharkiv region now makes $12 \%$ only, while the optimal one might be $15 \%$. So, about 80,000 ha of new forests must be created.

Most of the forest areas of the Kharkiv region belong to the state ownership (76.1\%), where the main sustained users are forest enterprises subordinated to the Kharkiv Regional Department of Forestry and Hunting.

The species composition of Kharkiv region forests is quite poor and mainly represented by English oak (Q. robur; 46\%) and Scots pine (P. sylvestris; 41\%). Species such as black locust ( $R$. pseudoacacia), silver birch (B. pendula), white poplar (P. alba), black poplar (Populus nigra L.) and common ash (F. excelsior) cover about $2 \%$ each. Other wood species occupy small areas.

By age group, the middle-aged stands are dominating $(79 \%)$, which contradicts the theory of 'normal forest' and does not comply with the optimal structure of forest distribution by age group.

The stands of Vovchansk (I), Balakliya (I,3), Huty $(I, 6)$ and Zhovtneve $(I, 9)$ Forest Economies have the highest site class. The stand density ranges from 0.62 (State Enterprise 'Krasnograd Forest Economy') to 0.73 (SE 'Kharkiv Forest Research Station'). The stands of Vovchansk Forest Economy have the largest growing stock volume $\left(321 \mathrm{~m}^{3} \times \mathrm{ha}^{-1}\right)$ and the stands of Krasnograd Forest Economy have the lowest one $\left(151 \mathrm{~m}^{3} \times \mathrm{ha}^{-1}\right)$.

At the present stage of society's development, issues concerning the role of urban forests in the context of sustainable development of world forests, prioritisation in ownership and economic entities, optimal stand distribution by age group, extension of the species range of forests and determining the optimal forest management principles are very important and invite further investigations. It will significantly increase water conservation, protection, sanitary, health, recreational, aesthetic, educational and other functions of urban forests.

\section{Conclusions}

Deterioration of water conservation, water protection, water-regulating, soil-protective, health and recreational properties of urban forests is an urgent problem to be addressed in urban areas. Having examined the condition and peculiarities of their growth, the following conclusions can be drawn:

1. The urban forests in the Kharkiv region fall under the public and communal domains. Forest management activities in them are virtually the same to date. 
2. To predict the condition of these forests and for their effective use, the inventory scheme for urban forests needs to be improved, as well as the management planning.

3. The range of species for urban forests is varied; however, the vast majority of forests have been formed by pedunculate oak (54\%) and Scots pine (32\%).

4. During silvicultural activities and landscape gardening, the wide introduction of other species with high ornamental value, aesthetic appeal and resilience against anthropogenic influences is appropriate.

5. The age structure of the forests is imbalanced. The middle-aged stands $(64 \%)$ are dominating in the age distribution of urban forests in Kharkiv region.

6. The relevant activities must be undertaken to optimise the forest resource structure for the urban forests in Kharkiv region.

\section{ReferenCES}

Alvey, A.A. 2006. Promoting and preserving biodiversity in the urban forest. Urban Forestry and Urban Greening, 5 (4), 195-201.

Anuchin, N.P. 1982. Forest inventory (in Russian). Lesnaya Promyshlennost, Moscow.

Basos, N. 2008. Recent problems of urban forestry in Ukraine. In: Proceedings of the International Youth Science Environmental Forum "ECOBAL - TICA2008" (eds.: M.P. Fiodorov, W. Hogland, V.Yu. Rud'), 26-28 June 2008, St.-Petersburg, Russia, 103-105.
Forest Code of Ukraine (in Ukrainian). Available at http://zakon5.rada.gov.ua/laws/show/3852-12 (access on 12 March 2019).

Kurakin, L.V. 2006. Forests of Kharkiv region (in Ukrainian). Zhurnalistskyi Fond Slobozhanshchiny, Kharkiv.

Miller, R.W., Hauer, R.J., Werner, L.P. 2015. Urban Forestry: Planning and Managing Urban Greenspaces. Waveland Press, Long Grove.

Musienko, S., Lyalin, O., Tkach, L., Babenko, V., Sułkowska, M. 2018. Characteristics and current situation of urban forests in Kharkiv region. Folia Forestalia Polonica, Series A - Forestry, 60 (3), 183-191.

Stolberg, F.V. 2000. Urban ecology (in Russian). Libra, Kyiv, Ukraine.

Sviridenko, V.E. 1989. Cutting for shaping of landscape (in Russian). USHA Publishing House, Kiev.

Tkach, V.P. 2012. Forests and forest cover in Ukraine: current state and prospects of development (in Ukrainian). Ukrainian Geographical Journal, 2, 49-55.

Tokareva, O.V. 2004. Value of suburban forests in the context of sustainable development (in Ukrainian). Scientific Bulletin of Ukrainian National Forestry University, 14.5, 232-236.

Vedmid, M.M., Meshkova, V.L., Zhezhkun, A.M. 2006. An algorithm for studying areas of low-value young stands in oak forests following the materials of forest surveying. Lisivnytstvo i Ahrolisomelioratsiya, $110,54-59$.

Vorobyov, D.V. 1967. Methodology of forest typological studies (in Russian). Urozhay, Kiev. 